\title{
Paralympics and Its Athletes Through the Lens of the New York Times
}

\section{Jeremy Tynedal ${ }^{1}$ and Gregor Wolbring ${ }^{2, *}$}

1 Faculty of Medicine, University of Calgary, 3330 Hospital Drive NW, Calgary, Alberta, T2N 4N1, Canada

2 Faculty of Medicine, Dept. Community Health Sciences, stream of Community Rehabilitation and Disability Studies, University of Calgary, 3330 Hospital Drive NW, Calgary, Alberta, T2N 4N1, Canada; E-Mail: gwolbrin@ucalgary.ca

* Author to whom correspondence should be addressed; gwolbrin@ucalgary.ca; Tel.:+1-403-210-7083.

Received: 11 December 2012; in revised form: 22 December 2012 / Accepted: 8 January 2013 / Published: 24 January 2013

\begin{abstract}
The purpose of this article is to analyze the coverage of the Paralympics in the New York Times (NYT) from the first appearance of the term Paralympics in 1955 up to 2012. We analyzed a) the textual imagery (not imagery intrinsic to pictures) of the Paralympics and its athletes, $b$ ) the representation of views and hopes of Paralympians and c) the visibility of the Paralympics and Paralympians within the NYT. We found that NYT coverage of the Paralympics and Paralympians is minimal and often portrays Paralympic athletes in stereotypical ways, such as being supercrips or suffering entities. In regards to the portrayal of therapeutic assistive devices of Paralympic athletes in the NYT, four themes are evident: a) the advancement of technology, b) the hierarchy between different therapeutic assistive devices, c) the relationship between the device and the athlete and d) the affordability of the device. We submit that the portrayal of the Paralympics, as evident in the NYT, for the most part does not help to further the discussion around a) the future of the Paralympics and its role within society, b) the relationship between the Paralympics and the Olympics and c) barriers of sport participation faced by athletes with disabilities on all levels, from recreational to competitive sport.
\end{abstract}


Keywords: Paralympics; Paralympic athletes; Paralympians; media; portrayal; New York Times

\section{Introduction}

Participation in sport has many health, social, economic and environmental benefits that encompass self-concept, self-esteem, reduced depressive symptoms, decreased anxiety, improved self-acceptance, changes in anti-social behaviour and enhanced psychological well-being [1]. Sport is of particular importance for improving the quality of life, self-esteem, independence and social integration of people with disabilities [2-7]. People with disabilities who participate in sport have significantly higher self-esteem and are more present in leadership positions [8,9], particularly in the sport industry, than are inactive people with disabilities [5-7]. Statistics Canada reports that only three percent of people with a physical disability consider themselves physically active [10]. A 2005 report by the Irish National Disability Authority highlights the lack of sport participation of people with disabilities in Ireland, England, the European Union, Canada and the USA [11]. According to the proceedings of a 2011 symposium organized by the US Inclusive Fitness Coalition (USIFC), titled Physical Activity and Sport for People with Disabilities [12], individuals with disabilities are almost three-times as likely to be sedentary as individuals without disabilities ( $29 \%$ vs. $10 \%)$; $56 \%$ of people with disabilities do not engage in any physical activity, compared to $36 \%$ of people without a disability; only $23 \%$ of people with disabilities are active for at least 30 minutes three or more times per week; 1.5 million students in public primary and secondary schools with physical impairments are excluded from having access to participate in athletic competitions. The USIFC further states that people with disabilities are more likely to experience attitudinal, social and programmatic barriers that may limit their inclusion in physical activity, fitness, sports, recreation and physical education. According to the International Paralympic Committee (IPC), the goal of the Paralympic Movement is "To enable Paralympic athletes to achieve sporting excellence and inspire and excite the world" [13]. With the advent of facilitating participation of people with disabilities into mainstream sport, it is important to examine the influence of the Paralympics on sport participation of non-Paralympians. Elisabeth Walker-Young, Canada's assistant Chef de Mission for the London 2012 Paralympic summer games, stated that she "is thrilled by the increase in participation at the Paralympics and the awareness the Games generate for people with a disability" [10]. At the same time, it frustrated her that "growth at the elite level has not "trickled down" into more people with disabilities becoming active" [10].

Diffusion of knowledge through printed media is an essential part of the fabric of society to enable social participation [14] and sustain political freedom and stable social order [15,16]. The media helps set the discussion agenda for society and creates the boundaries within which debate takes place [17]. In Grosjean v. American Press Co., 297 U.S. 233 (1936), the Supreme Court emphasized the important role of newspapers and magazines to inform the public of national affairs [18]. Critical theorist, Douglas Kellner, asserted that "media influence is so pervasive on our daily lives that often our thoughts, behaviours, styles and opinions are based on the mass media's actual construction of knowledge" [19]. Media representation is both a source and indicator of public opinion [20]. Mass 
media has the power to inform or not inform the public about an event or to construct reality from a particular perspective [21]. According to ethicist Simon Brisenden "the language used and the situation in which it is expressed will determine the message that goes out to those listening" [22]. The message circulated by media about the Paralympics is derived from how the news is prepared around the event in relation to the audience being targeted. In 1924, a member of the Carnegie foundation stated, "knowledge, however important, must be prepared in a great variety of ways for a great variety of minds or it fails to take hold" [23]. One of the major influences of mass media is its reinforcement of existing norms and attitudes [24]. Thus, it is important to examine how mass media, particularly the NYT, has represented the Paralympics. Through the construction of language and symbols used by institutions, groups and individuals, "rhetoric functions as a powerfully shaping instrument for creating conceptions of identity and positioning individuals relative to established social and economic hierarchies" [25]. Media coverage of the Paralympics is one indicator of public representations and attitudes toward sports for people with disabilities [9]. Disabled people have long questioned the use of ableist and disabling language in the media (including both the tabloids and so called "quality" newspapers) [26]. Many articles have focused on analyzing media coverage of the Olympics and Paralympics in general [9,27-31], and more specifically, the 1988 [32], 2000 [33-35], 2002 [36] and 2008 Paralympics [37], and highlighted various problems. However, there has yet to be a review of the coverage of sport related to people with disabilities, in general, and of the Paralympics, in particular, in the New York Times (NYT) — a newspaper that stated the importance of printed media as early as 1790 [14]. We used the NYT because it is a highly esteemed media source, internationally, winning 136 Pulitzer Prizes and citations [38] (three being from the "Sports of the Times" column) - more than any other news organization.

Many scholars have identified the NYT as a key gatekeeper in national news coverage. A study by Althaus and Tewksbury identified that people exposed to the Times for five days adjusted their overall agendas in part to that suggested by the newspaper [39]. Readers of the Times came away with systematically different perceptions of the most important problems facing the country. Iyengar and Kinder argued that the less knowledgeable readers are more susceptible to media-supplied cues about the importance of various issues; this perspective would suggest that agenda-setting effects among less knowledgeable readers should be larger [40].

Given the important role of the media to construct and transmit discourses to the public and, in particular, the self-understanding of the New York Times Company and the publicly perceived importance of the NYT, we submit that it is important to investigate how the NYT covers the Paralympics. The NYT has a long history of covering sport for people with disabilities, with coverage first appearing in 1894 [41]. Therefore, investigating the NYT allows us to examine the portrayal of the Paralympics from its beginnings. With this in mind, we chose to investigate: a) the textual imagery (not imagery intrinsic to pictures) of the Paralympics and its athletes, b) the representation of views and hopes of Paralympians, c) the visibility of the Paralympics and Paralympians and d) the portrayal of therapeutic assistive devices of Paralympic athletes within the NYT from 1955-2012. 


\section{Method}

We conducted a thematic and descriptive textual analysis of the NYT in order to examine deeper underlying issues related to the textual imagery and visibility of the Paralympics and Paralympic athletes, historically and contemporarily. The NYT was systematically searched using [1] the ProQuest search engine (provided by the University of Calgary) for articles from 1851-2006 and [2] the ProQuest search engine (provided by the University of Calgary) for articles from the latest East Coast Edition (2007-2012). Three search strategies were employed. First, we searched terms that are known to be used to cover what we now call the Paralympics. Using the keyword combination 'Olympiad' and 'disabled' we found one article in the NYT from 1920 that wrote about the Antwerp Olympiad covering the problems for the British Olympic Committee of raising money due to appeals of war charities, such as Field Marshall Haig's fund for disabled veterans [42]. An article from 1952 covered the Stoke Mandeville games, the games that are seen as the precursor to the Paralympics. This article used the term "Olympiad for Paralyzed Persons" [43]. The 1976 fifth Summer Paralympic games, called Torontolympiad, were not covered in the NYT. However, the main focus of this study was the coverage of articles that used the term Paralympics. Therefore, our second search strategy was to search the full text of the NYT for the keywords Paralympic/Paralympics/Olympic/Olympics to obtain first an appreciation for how often the Paralympics were covered in comparison with the Olympics (Table 1). Finally, in order to identify the Paralympics covering documents for further thematic and descriptive textual analysis, the NYT was searched using the keywords Paralympic/Paralympics in the text of NYT articles. Searching the NYT from 1851-2006 revealed that the first article that used the term Paralympics appeared in 1955 [44]. Given the timespan of the use of the term Paralympic/s from 1955-2012, we divided our results and analysis into three periods: 1955-1987, 1988-2007 and 20082012. The first period, which begins in 1955, marks the start of NYT coverage of the Paralympics with using the term Paralympics, with the first article being 11 Fly to Paralympics [44]. The second period begins in 1988, when the Seoul Paralympics became the first Games that took place in the same city and on the same playing fields and courts as the Olympics [45]. Supported by the NYT, we perceive 1988 as a milestone in Paralympic development, because Seoul demonstrated that it was possible and desirable to bring Olympic-level organization to the Paralympics [45]. We choose the 2008 Beijing Paralympics as the beginning for the third period, because the Games attracted a record number of viewers for a Paralympic Games [46], higher than in previous games. The third period ended in 2012 with the London games. Our searches generated 246 articles. We saved articles as PDF files and optically characteristically recognized (OCR) them into editable files, which allowed us to highlight and code text in order to identify common themes in each article. We used Adobe Acrobat X Pro to analyze the data in two ways: [1] keyword frequency analysis and [2] in-depth content and thematic analysis of individual articles. As we read each article, we developed a list of codes (covering the research question) in an iterative fashion. Codes covered among others perception and portrayal of the Paralympics, Paralympians and therapeutic assistive devices used by Paralympians. Codes covered further sport disciplines, names of Paralympians, types of disabilities of athletes and stereotypical terms of disabilities. The literature underwent separate analysis by both authors to increase the reliability of our findings. 


\section{Results and Discussion}

\subsection{Visibility of the Paralympics versus the Olympics}

People with disabilities have taken part in competitive sport for some time. Some of the earliest accounts of competitive sports for people with disabilities describe sport organized by members of deaf communities as early as 1888 and in schools for the blind in 1909 [47]. Visibility is one important aspect for sport activities of people with disabilities. The earliest mention of competitive sport for people with disabilities in the NYT was of sport competitions for 'deaf' and 'mute' communities in 1894 organized by the Deaf and Dumb Institute at the Young Men's Christian Association [41]. With regards to the Paralympics, various Paralympic athletes question the lack of coverage of the Paralympics in the media [9]. In order to ascertain the visibility of the Paralympics in the NYT, we first looked at the relative visibility of the Paralympics and Olympics (in this one case, searching the ProQuest database mentioned before for the words Paralympic/Paralympics and Olympic/Olympics). We found that the Olympics was roughly fifty-times more covered than the Paralympics (Table 1).

Table 1. Visibility of articles in the NYT covering the Paralympics and Olympics by period (1955-2012).

\begin{tabular}{|l|c|c|c|c|}
\hline Event & $\mathbf{1 9 5 5 - 1 9 8 7}$ & $\mathbf{1 9 8 8 - 2 0 0 7}$ & $\mathbf{2 0 0 8 - 2 0 1 2}$ & Total \\
\hline $\begin{array}{l}\text { Number of } \\
\text { articles covering } \\
\text { the Paralympics }\end{array}$ & 49 & 115 & 82 & 246 \\
\hline $\begin{array}{l}\text { Number of } \\
\text { articles covering } \\
\text { the Olympics }\end{array}$ & 1,296 & 7,100 & 2,091 & 10,487 \\
\hline
\end{tabular}

In a second step, we looked at the visibility of the Paralympics by counting NYT articles that covered a given Paralympic game one year before to one year after its occurrence (with the exception of London 2012, where we counted articles up to November $1^{\text {st }}, 2012$ (Fig. 1)). Figure 1 reveals that there is an increase in visibility over time in summer Paralympics (the number for London 2012 is lower because we have not reached the one year after London 2012 stage yet; given where the numbers are already, we believe that London 2012 will outperform Beijing 2008 in terms of coverage in the NYT). The numbers are much less encouraging for the winter Paralympics, where no clear trend of increasing visibility is evident. In general, there appears to be a bias in the NYT of coverage of the summer Paralympics games over the winter Paralympic games (Fig. 1). 
Figure 1. Number of articles covering the Paralympic winter (grey color) and summer (black color) games in the New York Times (NYT) (1960-2012) (as a percent of the total number of $n=246$ articles).

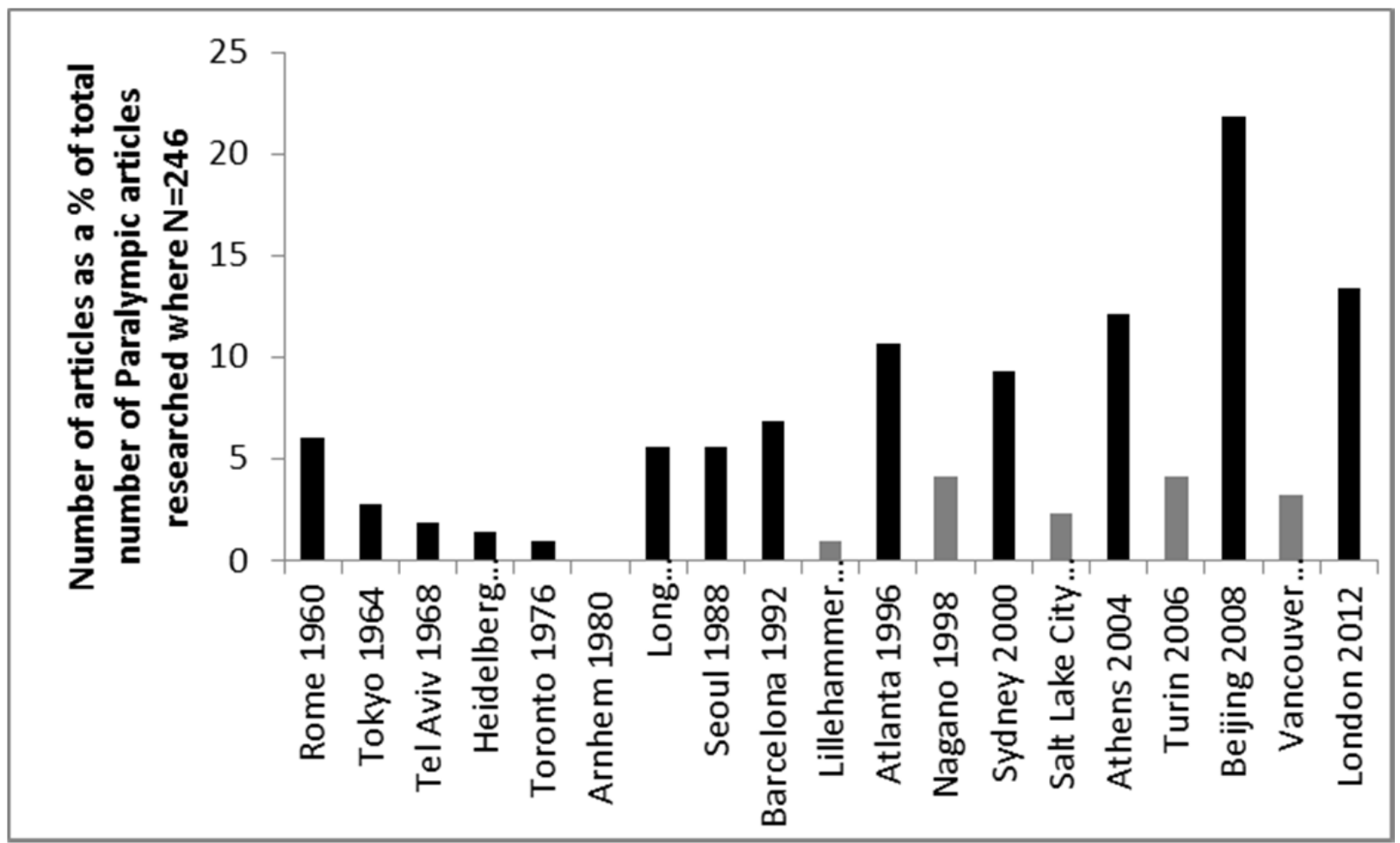

\subsection{Visibility of Different Paralympic Sport Disciplines}

As much as the overall visibility of the Paralympics is important, so is the visibility of individual sport disciplines, given that athletes in all disciplines work very hard to qualify for the Paralympics. We found a gradient of visibility related to disciplines (Table 2). Most of the disciplines visible are summer Paralympic disciplines. With the exception of skiing, we found very little coverage of winter Paralympic disciplines in the NYT. 
Table 2. Visibility of coverage in the NYT of sport disciplines in the Paralympics (1955-2012).

\begin{tabular}{|c|c|}
\hline Sport & Number of Articles \\
\hline Basketball & 70 \\
\hline Athletics & 53 \\
\hline Skiing & 48 \\
\hline Table tennis & 30 \\
\hline Archery & 24 \\
\hline Shot put & 23 \\
\hline Discus & 22 \\
\hline Javelin & 20 \\
\hline Cycling & 19 \\
\hline Tennis & 16 \\
\hline Soccer & 13 \\
\hline Rugby & 11 \\
\hline Weight lifting & 11 \\
\hline Swimming & 11 \\
\hline Slalom & 9 \\
\hline Shooting & 8 \\
\hline Fencing & 7 \\
\hline Yachting & 6 \\
\hline Volleyball & 6 \\
\hline Sledge hockey & 5 \\
\hline Sailing & 5 \\
\hline Pentathlon & 4 \\
\hline Darts & 3 \\
\hline Tandem cycling & 3 \\
\hline Triathlon & 3 \\
\hline Equestrian & 3 \\
\hline Snooker & 2 \\
\hline Club throwing & 2 \\
\hline Heptathlon & 2 \\
\hline Darchery & 2 \\
\hline Judo & 2 \\
\hline Ping-pong & 1 \\
\hline Bowling & 1 \\
\hline
\end{tabular}

\subsection{Visibility of Paralympians}

A third aspect of visibility in regards to the Paralympics is the visibility of Paralympic athletes (Table 3). In general, very few Paralympians were mentioned by name in the NYT, and the Paralympians mentioned were not mentioned in many articles. The title of most 'famous' Paralympian, at least temporarily, belongs to Oscar Pistorius $(n=32)$. The main focus of the NYT coverage of Pistorius from 2007-2012 was the controversy around him wanting to compete in the 2008 Beijing Olympics [48] and 2012 London Olympics, with all articles being supportive of his participation in the Olympics. Beyond the coverage of the Olympic angle, the NYT expressed a high expectation for Pistorius to win the 200 and 400 meters at the Beijing Paralympics [49] and characterized him as 
"admirable" [50] for running on prostheses. The NYT also represented competitive rivalry between Paralympians and Pistorius, where the NYT envisioned that other Paralympians should "knock off Pistorius" [51]. During the London Paralympics, when Alan Oliveira placed first in the 200-m and Pistorius placed second, the NYT called it a "loss" and "upset" [52] and criticized Pistorius for questioning the length of the blades with which Oliveira ran [53] instead of highlighting Oliveira's gold medal.

Natalie du Toit $(n=10)$ was mentioned in the NYT for competing in the 2008 and 2012 Olympics and was compared with Pistorius' not yet competing in the Olympics and focused on the fact that du Toit did not provoke a debate when qualified for the Beijing Olympics due to her not wearing an artificial leg in her swimming competitions [54]. Apart from being covered with Pistorius in the NYT, $\mathrm{du}$ Toit was recognized individually for being the first female with an amputation to swim in the Olympics [54] and for carrying the South African flag at the opening ceremony of the Paralympics and Olympics [55]. Furthermore, she is a decorated athlete who won five gold medals and a silver medal in the Athens Paralympics [56] and four gold medals in the Beijing Paralympics [57].

Right along with du Toit in visibility is Marla Runyan ( $n=7)$, who competed in the $1500-\mathrm{m}$ at the 2000 Olympics in Sydney [58]. The NYT portrayed Runyan's athletic career as the feel-good success story of "fierce determination [...] to defeat some incredibly long odds," [59], which was vision impairment from Stargardt's disease. Swimmer Jessica Long $(n=7)$, having a double below-the-knee amputation, was mentioned in the NYT for her competitive ability to train against able-bodied swimmers and beat most of them. In 2006, Long won nine gold medals in a world competition in South Africa [60]. In the years 2007, 2008 and 2010, six articles of the NYT covered Long being awarded the E. Sullivan Award as her nation's most outstanding amateur athlete.

Paralympians mentioned once in the NYT include: Matt King, Victor Calise, Ivy Gunter, Kevin Bramble, Casey Martin, Antonio Rebollo, Geoff Mstesky, Robert Hawkes, Bob Wieland, Thecla Mitchell, Paddy Rossbach, Joseph Bowser, Aaron Schiedes-stargadts, Kim Borowitz, Mike Savicki, Laura Schwanger, Sebastian DeFransesco, Said Rasul Kadhim, Kendall Bailey, Andy Yohe, Andy Soule, Trischa Zorn, Jim Mastro, Josh George, Sergei Shilov, Bradley Walker, Blake McMinn, Jim Abbott, Doug Pringle, Kamel Ayari, Joe Dowling, Nina Kirn Tony Nogueira, Ernst Van Dyk, Edith Hunkeler, Marin Morrison, April Holmes, Scott Winkler, Hou Bin, Tyson Gay, Heba Said Ahmed, Andrea de Mello and SuGui Kriss, Alex Zanardi, Donna Ponessa, Anthony Dawson, Amaya Alonso, Dale Dedrick, Ian Jones, Matthew Cowdrey, Veronika Vadovicova, Manuela Schmermund, Nilda Gomez Lopez, Simon Richardson, Masaki Fujita, Greg Ball, Guo Huaping, Cui Na, Laroslav Semeneko, Anjali Forber-Pratt, Sarah Reinersten, Im Dong-hyun, Cheng Chu Sian, Lex Gillette, Chantal Petitclerc, Daniela di Toro, Cameron van der Burgh, Khotso Mokoena, Chad le Clos, Matt Scott, Jarryd Wallace and Blake Leeper.

Paralympians Karoly Takics and Liz Hartel, who are known to have competed in the Olympics, were not mentioned in the NYT. 
Table 3. Visibility of Paralympians mentioned more than once in the NYT 1955-2012 (by decreasing order of hit-count) *Indicates competed in the Olympics

\begin{tabular}{|c|c|}
\hline Paralympian & Number of articles \\
\hline *Oscar Pistorius & 32 \\
\hline *Natalie du Toit & 10 \\
\hline *Marla Runyan & 7 \\
\hline Jessica Long & 7 \\
\hline Marlon Shirley & 6 \\
\hline Dennis Oehler & 6 \\
\hline Erin Popovich & 5 \\
\hline *Neroli Fairhall & 4 \\
\hline Kortney Clemons & 4 \\
\hline Aimee Mullins & 4 \\
\hline Alonzo Wilkins & 3 \\
\hline Brian McKeever & 3 \\
\hline *Natalya Partyka & 3 \\
\hline Nick Scandone & 3 \\
\hline Alan Oliveira & 3 \\
\hline Melissa Stockwell & 3 \\
\hline Chris Waddell & 3 \\
\hline Bill Demby & 3 \\
\hline Helene Hines & 3 \\
\hline Tony Iniguez & 3 \\
\hline *George Eyser & 2 \\
\hline Mark Zupan & 2 \\
\hline Scott Hogsett & 2 \\
\hline Andy Cohn & 2 \\
\hline Jeff Skiba & 2 \\
\hline *Todd Schaffhauser & 2 \\
\hline John Register & 2 \\
\hline Casey Martin & 2 \\
\hline David Weir & 2 \\
\hline Jerome Singleton & 2 \\
\hline Brian Frasure & 2 \\
\hline Korie Homan & 2 \\
\hline Esther Vergreer & 2 \\
\hline Sharon Walraven & 2 \\
\hline Jiske Griffioen & 2 \\
\hline Paul Schulte & 2 \\
\hline Jerrod Fields & 2 \\
\hline Amy Palmiero-Winters & 2 \\
\hline Damian Lopez Alfonzo & 2 \\
\hline Jackie Joyner-Kersee & 2 \\
\hline Jim Bob Bizzell & 2 \\
\hline
\end{tabular}




\subsection{Visibility of Disabilities}

It is well known that media covers different disabilities in different ways [61]. The same is true for the NYT's coverage of different disabilities of athletes in the Paralympics. Physical disabilities, such as "amputation" $(n=59)$, "blind" $(n=22)$, "polio" $(n=14)$ and "paralyz*/sis*" $(n=30 / n=5)$ were common in covering athletes with disabilities. Whereas, "cerebral palsy" $(n=8)$, "Stargardt's Disease" $(n=5)$ "deaf" ( $\mathrm{n}=5)$, "vision impaired" $(\mathrm{n}=5)$, "intellectual disabilities" $(\mathrm{n}=5)$, "hearing impaired" $(\mathrm{n}=2)$ and "autism" ( $\mathrm{n}=2)$ lead to very little coverage (Table 4). As to intellectual disability, the NYT reported on the serious problems regarding the determination of eligibility of athletes [62], as cited by the International Paralympic Committee (IPC), covering the banning of all athletes with intellectual disabilities from competing in any Paralympics event because Spain's gold medaling basketball team was found to have players that did not have intellectual disabilities. It was only recently in 2010 that the IPC welcomed back the opportunity for athletes with intellectual disabilities to compete in the 2012 London Paralympics.

Table 4. Visibility of coverage in the NYT of disabilities of athletes (1955-2012)

\begin{tabular}{|l|c|c|c|c|}
\hline \multicolumn{5}{|c|}{ Number of Articles } \\
\hline Disability & $\mathbf{1 9 5 5 - 1 9 8 7}$ & $\mathbf{1 9 8 8 - 2 0 0 7}$ & $\mathbf{2 0 0 8 - 2 0 1 2}$ & Total \\
\hline amput* & 2 & 27 & 30 & 59 \\
\hline paralyz & 10 & 13 & 7 & 30 \\
\hline blind & 1 & 13 & 8 & 22 \\
\hline parapleg* & 7 & 8 & 4 & 19 \\
\hline polio & 6 & 5 & 3 & 14 \\
\hline cerebral palsy & - & 5 & 3 & 8 \\
\hline spinal cord injur* & - & 4 & 2 & 6 \\
\hline deaf & - & 4 & 1 & 5 \\
\hline Stargardt's & - & 2 & 3 & 5 \\
\hline visual*/vision impair* & - & 1 & 4 & 5 \\
\hline intellectual* disab* & - & 2 & 3 & 5 \\
\hline paralys* & 1 & - & 4 & 5 \\
\hline quadrapleg*/quadripleg* & - & 4 & - & 4 \\
\hline (develop)mental* disab* & - & 1 & 2 & 3 \\
\hline autism & - & 1 & 1 & 2 \\
\hline hearing impair* & 1 & - & 1 & 2 \\
\hline dwarfism & - & 1 & 1 & 2 \\
\hline multiple sclerosis & - & - & 2 & 2 \\
\hline Disabities, such & - & - & 4 & \\
\hline
\end{tabular}

Disabilities, such as muscular dystrophy, juvenile arthritis, multiple sclerosis, cystic fibrosis, spina bifida, systemic lupus, Lou Gehrig's disease, Down syndrome, Klippel-Trenaunay-Weber syndrome and Klinefelter's syndrome were covered once in the NYT.

\subsection{Portrayal of the Paralympics and Paralympic Games}

As important as visibility is for the Paralympics, if the visibility is not based on the right type of coverage, visibility can lead to problems. The following themes were identified; respect and attitude toward the Paralympics, financial struggles of Paralympic games, accessibility of people with 
disabilities and classification of athletes. Regarding the theme of respect, various NYT articles reported that the Paralympics does not receive the same respect from corporate sponsors as does the Olympics [63]. During the Atlanta games, the NYT reported that Paralympic organizers complained that Olympic organizers failed to deliver on their promises to coordinate the changeover of staff members, transfer equipment and see to maintenance and repair of everything from broadcasting equipment to athletes' dormitories [64]. One article stated that the United States Olympic Committee (U.S.O.C.), which oversees programs for the Olympics and Paralympics, reportedly provides less direct financial assistance, health-insurance opportunities and performance bonuses to Paralympic athletes than it does to Olympians in comparable sports [65]. In exposing disrespect toward the Paralympics, one article in the NYT stated, "the advertising industry does not have the right attitude" [63] toward the Paralympics. Another article talked about American corporations staging a feeding frenzy to be identified with the Olympic movement, but shying away from the Paralympics [66]. This was the case during the Atlanta Paralympics, when six corporate sponsors of the Olympics did not extend their sponsorship to the "less costly Paralympics" and refused to legally release the organizers to find other companies among their competitors to sponsor the event [45]. Dr. LeRoy T. Walker, the 1996 president of the U.S.O.C., urged that the Paralympics, which followed the summer Olympics in Atlanta, be held before future summer games. The switch was seen to allow the Paralympics to receive more recognition and serve as an "administrative staging vehicle for future summer games" [64] (there is no recorded suggestion for the same switch to occur for the winter games). On the other hand, a NYT article described Russia as "a black belt in judo" [67], which has made athletic development of the Paralympics a national priority. "After the team took first place in the 2006 winter games in Turin, Italy, Russia's Prime Minister [at the time] signed a decree making cash prizes awarded by the government to medal winners equal for Olympians and Paralympians. Additionally, the government increased training stipends for disabled athletes, as well as money for foreign travel" [67]. The same article discussed the Moscow government's inconsideration of accessibility parameters for people with disabilities that "have turned out horribly" [67], quoting Natalya Bakhmatova, from the Moscow-based disabled rights group Perspektiva, and Sergei Shilov, who competed in both the summer and winter Paralympics. The same article links the success of the Russian Paralympic team to changes for the community of people with disabilities at large. It highlighted that since the Paralympic team's success, the Russian government has vowed to do more to ease the lives of the country's disabled through "efforts that will be under scrutiny as Russia prepares to hold the 2014 Winter Olympics and Paralympics in Sochi" [67].

The issue of disability classification of Paralympic athletes is captured in the headline "At the Paralympics, the first thing judged is disability"[68] Many articles in the NYT [68-72] discuss this headline's message of classification of disabilities as a barrier to sport participation for athletes with disabilities. Three sub-themes emerged around classification: [1] athletes competing in higher classification grades having an unfair advantage over their athletic competitors (e.g., techno doping), [2] athletes competing in lower classification grades having an unfair advantage over athletes classified as more disabled, [3] diversification of disabilities, which makes it difficult to classify athletes and, thus, the classification of athletes frequently change, where they are normally moved to a higher classification grade. The article At the Paralympics, the first thing judged is disability [68] gives voice to Paralympic equestrian Anthony Dawson, Christine Meaden, chief classifier for the International 
Paralympic Equestrian Committee, and Peter van der Vliet, the International Paralympic Committee's chief medical classifier, who raise the issue of the difficulty of classifying an athlete in the Paralympics. A quote by Peter van der Vliet, who talked about the London 2012 Paralympics, illustrates the felt difficulty, where " 245 athletes have been deemed borderline-hovering between one grade and another-and have been reassessed at the games. Forty have been moved to different classifications, and eight athletes (in track and field, swimming and judo) have been ruled ineligible and sent home because they did not meet "the minimal disability criterion" [68].

One issue not discussed in the NYT is the Paralympic eligibility issue that arises if a Paralympian competes in the Olympics. The IPC classification code states, "5.3 The impairment should limit the Athlete's ability to compete equitably in elite sport with Athletes without impairment" [73]. Rule 5.3. implies that Paralympic athletes must prove that they cannot compete against Olympic athletes in order to compete in the Paralympics. This raises the question of how a Paralympic athlete who competes in the Olympics can also compete in the same year in the Olympics, a question not really debated, although Paralympic athletes, such as Natalie du Toit and Oscar Pistorius, competed in the Olympics and Paralympics of the same year.

\subsection{Portrayal of Paralympians.}

How one is portrayed in the media can have positive or negative consequences. Media is known to stereotype people with disabilities [74]. We identified two stereotyping narratives in the NYT, the supercrip [74-78] and the suffering entity (Table 5). We identified other negative imagery (Table 5) and medical imageries (Table 5) of people with disabilities. The term "victim" was used (n=10) (first appearing in 1955 and latest appearing in 2004) to stereotype athletes with disabilities, particularly athletes with polio. Headlines of early coverage of the Paralympics, Polio Victims, All with PanAmerican Airways, Tell of English Triumphs and Team of Polio Victims to vie in International Games indicate the victimization of athletes with polio in the NYT. The NYT had many examples that showed the Paralympics within medical rhetoric and described the athlete with disability in terms of disease $(n=27)$, impairment $(n=22)$, defect $(n=9)$ or ill $(n=5)$ (all terms first appearing in 1955 and latest appearing in 2012).

Conversely, articles in the NYT described Paralympic athletes in superlative terms (Table 6). According to Hardin and Hardin "[d]isability advocates define the supercrip as the presentation of a person, affected by a disability or illness (often in the prime of life), as 'overcoming' to succeed as a meaningful member of society and to live a 'normal' life" [28]. Critics charge that the 'supercrip' media model - a standard framework for stories about disabled 'heroes' - serves as a hegemonic device that keeps people with disabilities at the bottom of the social hierarchy and deflects the culture's responsibility for its ableist infrastructure [79]. Use of the supercrip stereotype exhibiting terms, such as "courage" $(\mathrm{n}=12)$, "special" $(\mathrm{n}=27)$, "hero" $(\mathrm{n}=11)$ and "extraordinary" (n=11) (all terms first appearing in 1955 and latest appearing in 2012) constructed societal marginalization of athletes with disabilities by comparing them with athletes without disabilities, just as how the term "normal" brings into scope the existence of "different". The supercrip image is present in the NYT as early as 1955 , when the Times wrote about the attention received by athletes with polio who were employed [80]. The 1955 article wrote about Pan-American Airways sponsoring eleven of their 
employees with polio to compete in the fourth international Paralympic Games at Stoke Mandeville. A follow up article wrote about the recognition received by Pan-America. Visiting officials came from other countries to study the Pan-American program because of their amazement that one company had hired so many physically "handicapped" $(n=40)$ people [80] in a society where employment of people with disabilities were under-represented in the media. As written, we see the focus on having a job as something special to fall into the supercrip category, as the article did not portray having a job as something normal. As written, the article left the impression that being a Paralympian might be attached to certain abilities that also increases ones chance of having a job.

Table 5. Visibility of coverage in the NTY of negative terms used to stereotype athletes with disabilities (1955-2012)

\begin{tabular}{|c|c|c|c|c|}
\hline \multicolumn{5}{|c|}{ Number of Terms } \\
\hline Term & 1955-1987 & 1988-2007 & 2008-2012 & Total \\
\hline injur* & 2 & 12 & 30 & 44 \\
\hline handicap & 14 & 18 & 8 & 40 \\
\hline limit* & 2 & 11 & 16 & 29 \\
\hline disease & 2 & 5 & 20 & 27 \\
\hline impair* & 2 & 11 & 9 & 22 \\
\hline severe & - & 6 & 7 & 13 \\
\hline$(\mathrm{ab})$ normal & - & 5 & 6 & 11 \\
\hline victim & 5 & 5 & - & 10 \\
\hline health* & 2 & 5 & 3 & 10 \\
\hline defect & - & 3 & 6 & 9 \\
\hline bound & 1 & 3 & 5 & 9 \\
\hline cripple* & 6 & 3 & - & 9 \\
\hline participant & 2 & 4 & 2 & 8 \\
\hline confine* & 3 & 3 & - & 6 \\
\hline unusual & 2 & 2 & 2 & 6 \\
\hline charit* & - & 6 & - & 6 \\
\hline affect* & 1 & 1 & 4 & 6 \\
\hline ill* & 1 & 3 & 1 & 5 \\
\hline devastat* & - & 1 & 4 & 5 \\
\hline trauma & - & 3 & 1 & 4 \\
\hline disadvant* & - & 2 & 2 & 4 \\
\hline afflict* & - & 1 & 2 & 3 \\
\hline (physically)challenged & 1 & - & 2 & 3 \\
\hline disadvantage* & - & 2 & 1 & 3 \\
\hline hardship & 1 & - & 1 & 2 \\
\hline
\end{tabular}

Another theme we found is the emphasis being placed on winning language, such as "victor*" $(\mathrm{n}=48)$ and "beat" $(\mathrm{n}=42)$ (all terms first appearing in 1955 and latest appearing in 2012). Shown throughout the NYT is also the narrative of athletes with disabilities as being a source of role modeling and inspiration $(n=16)$ in preserving the 'pure form' $(n=6)$ of the Olympics. One article described the Barcelona Paralympics as making "a worldwide glow that would remind us of the Olympic flame" and concluded that "the Paralympic Games are for all of us" [81]. 
The themes we found have been reported by others who have analyzed other media that has covered sport for people with disabilities (i.e., supercrip [28,82] or focused on the negative aspect of bodily situations of people with disabilities) [83]. Often, media presents disability sport events as humaninterest stories rather than elite level sports competitions [84]. Popular human-interest stories typecast disability as a personal tragedy that occurs to random individuals and requires them to adapt [26]. The narrative stresses for athletes to exert superhuman efforts to succeed, or they deserve our pity, or they are fearful because of their terrible limitations [85]. The NYT provokes the same narrative of charitable discourse (happy to be going rather than aiming for a gold medal) with the onlooker attitude of "Oh, it's so good to see you out here. You just threw that one foot and we're so glad!" [86]. Furthermore, media disempowers athletes with disabilities through patronizing and stereotypical reporting [87]. For example, Judy Benoit, a swimming and table tennis gold medalist, normalizes the courageous perception others have of her, due to her competing in sport, by insisting that she is not courageous at all, she just happens to do her sport from a chair [88]. Being portrayed as a superhero in the Thierry Mugler campaign made Pistorius slightly uncomfortable, but he looks at it by "not conforming to what are believed to be the limits of others, but [by] striving to make the limits of your own. That is an analogy [Pistorius is] more comfortable with when it comes to being a superhero" [89]. An article in the NYT represents "polio survivors to emerge with stubborn determination rather than the scars of social disdain [being] Type A personalities [where their] support group at home is so busy [they] barely have time to meet" [90].

Table 6 Visibility of coverage in the NYT of supercrip stereotype exhibiting terms (19552012).

\begin{tabular}{|c|c|c|c|c|}
\hline \multicolumn{5}{|c|}{ Number of Terms } \\
\hline Term & 1955-1987 & 1988-2007 & 2008-2012 & Total \\
\hline able-bod* & 3 & 27 & 46 & 76 \\
\hline victor* & 20 & 20 & 8 & 48 \\
\hline beat & 2 & 31 & 9 & 42 \\
\hline defeat* & 4 & 20 & 11 & 35 \\
\hline special & 3 & 14 & 10 & 27 \\
\hline achievement & - & 8 & 8 & 16 \\
\hline inspir* & - & 7 & 9 & 16 \\
\hline courag* & 2 & 7 & 3 & 12 \\
\hline hero* & 2 & 5 & 6 & 13 \\
\hline extraordinary & 1 & 4 & 6 & 11 \\
\hline amaz* & 2 & 3 & 6 & 11 \\
\hline overcome/overcame & 1 & 3 & 2 & 6 \\
\hline pure/purity & - & 1 & 5 & 6 \\
\hline warrior & - & 2 & 3 & 5 \\
\hline brav* & - & 2 & 1 & 3 \\
\hline freedom & - & - & 3 & 3 \\
\hline conquer* & 1 & - & 1 & 2 \\
\hline
\end{tabular}

The NYT reported on Paralympians being frustrated with the language used to describe them at Paralympic opening ceremonies as participants $(n=8)$ who had achieved $(n=16)$ victory $(n=48)$ even 
before they arrived at the games [91]. Society's notion of amateurism and lack of seriousness of Paralympic competition[92] was evident in the NYT, such as in an article describing groups of smiling young men and women with their tanned faces glowing with health and the good fellowship of friendly competition [93]. A NYT advertisement described the perceived heroic nature of Paralympians by distinguishing the Paralympics from the Olympics stating, "The Olympics is where heroes are made. The Paralympics is where heroes come" [47]. Hurt felt by the semantics of society toward Paralympians is shown to have stretched across historical and contemporary times, as noted by 100meter wheelchair sprinter, Ross Davis, who wants to be treated like an athlete and wants to erase the superlatives that are given as compliments, because he feels that these superlatives are evidence that perceptions are not changing [94]. Matt King, tandem cyclist, speaks of the importance of changing the supercrip image, of not seeing himself as extraordinary as a blind person being in the Paralympics, but as normal [95]. He feels that the disability is often used to expect less from the person and that this has negative consequences [95]. The NYT, however, in the same article, did not accept King's view stating, "Despite his denials, King is indeed exceptional" [95].

\subsection{Vision and Hopes of Paralympians}

Everyone has visions and hopes. The desire of Paralympians to compete in the Olympics is one theme evident in NYT articles $(n=42)$, although it has not been elaborated on as to why. One article covered du Toit, a Paralympian who competed in the Olympics, and highlighted that being in the Olympics is about being like everyone else [54]. It has not only been reported as being a dream for the disabled athlete, but also as a dream for people linked to the athletes, such as coaches, family, spectators and officials of disability sport organizations [59]. Sometimes, the athletes are quoted on how great it would be to compete in the Olympics, when they competed only in the Paralympics [96]. Similarly, in the NYT, competing in the Paralympics is labelled as fulfilling the Olympic dream [97]. Over time, various initiatives started to generate some blending between the Paralympics and the Olympics, and initiatives are still underway $[98,99]$. The NYT reported, for example, that Meeche White, chief executive officer and founder of the National Ability Center, is working to include the adaptive bobsled as an official sport in the 2014 Sochi Paralympic Winter Games [100].

\subsection{Portrayal of Assistive Devices}

Therapeutic assistive devices play an important role in the lives of many people with disabilities, whether they are athletes or not. Four themes can be identified in the NYT with regards to the portrayal of therapeutic assistive devices of Paralympic athletes: a) the advancement of technology, b) the hierarchy between different therapeutic assistive devices, c) how the athlete is perceived by themselves and others as using the device and what the device means to the athlete (whether it is enabling or limiting) and d) the affordability of the device.

As to the first theme, the advancement of technology, the NYT portrays therapeutic assistive devices as constantly evolving [101] and improving [102] and as breaking boundaries [96]. For the evolution of the push-rim wheelchair to the hand-cycle, Helene Hines stated in 2000 that "the next few years you will have some arguing about it [...] It might be two separate divisions, but [...] eventually wheelchair people will move into a hand-crank because they will want to keep enjoying racing, and 
that's where the longevity of the sport is" [103]. Some hand-cyclists say "their mode of competition is part of the sport's evolution, as sharkskin suits are to swimming and clap skates are to speed skating [...] Hand-cycling is now included in the disabled world cycling championships and in the cycling portion of the Paralympics" [103].

We found two other interrelated themes: a) textual imagery of therapeutic assistive devices athletes use and b) the relationship between the athletes and their therapeutic assistive devices. As to the therapeutic assistive devices, glorified in the NYT were prosthetic leg devices $(n=14)$ through their forthcoming expectation to "open up the world" for their wearers. A 1988 article described the feeling as "Freedom $(n=3)$. Being unchained. Unlocking the door and walking into the sunshine. Exhilarating" [104]. Wheelchair assistive devices $(n=33)$ were at the bottom of the hierarchy, receiving negative perception $(n=19)$ around their attachment to their users, where the person with disability was described as being "bound" ( $\mathrm{n}=9$ ) (first appearing 1967 and latest appearing in 2012) or "confined" $(n=7)$ (first appearing in 1960 and latest appearing in 2012) to a wheelchair. A negative view of therapeutic assistive devices is also expressed by the NYT quote, "The chair won't beat me," [88] where the tool is deemed as threatening the user's identity and agency. Conquering one's assistive device is found $(n=2)$ times [105]. Moreover, articles in the NYT discussed athletes "getting out of the chair"[106] and returning to their previous bodily form and function. Emphasis was placed on highlighting negative experiences of "men [88] and women [107] who, through some misfortune, [were] unable to walk" [93].

The NYT also includes articles that outline the unique qualities of wheelchairs $(n=17)$. However, although the first article appeared in 1968, this narrative did not become prevalent until 2008. A 2005 NYT article described wheelchair rugby as a sport rather than a feel-good handicapped event [108]. Wheelchair rugby athletes were described as combatants outfitted like warriors, but without helmets, strapped into armoured, custom-made wheelchairs that collide in a kind of human demolition derby [109]. The description of wheelchair rugby provided a counter narrative to the demonization of wheelchairs, which the rugby athletes used, where the wheelchairs helped liberate them by enabling them to "hit something as hard as [they] possibly [could]" [110] in a sport, otherwise known as Murderball, that displayed ferocity of competition in full-body immersion [108]. The rugby athletes demonstrated breaking out of the confinement box that defined them as "being stuck in a wheelchair" [108] by helping people realize that they do not live in them. It's good for people to realize otherwise" [108]. Athletes, such as Mike Savicki, highlighted the difference in the perception of wheelchairs, where so-called able-bodied people might look at a wheelchair and see confinement, where to Savicki "racing is like a simplified version of life. It is you and the chair and how fast can you go. No doors in the way, no curbs to bounce over, it's just, "See how fast you can go"' [111]. Wheelchair racer Mike Rodolph also was portrayed as identifying positively with his wheelchair, which he sees as enabling him to "surpass able-bodied athletes [and] blow them away in track [and] open up whole new horizon[s]"[112] In the NYT, $(n=29)$ articles were found to have a positive take on the relationship between therapeutic assistive devices and disabled athletes, where athletes embraced the therapeutic assistive device they used, namely rugby wheelchairs, tandem bikes, prostheses (i.e., legs) and the hand-cycle) as a part of their identity. 
The fourth theme mentioned only once is around affordability, where the article highlights that "devices like the carbon fibre blades worn by Pistorius and Oliveira are often too costly for people from poor countries" [113].

\section{Conclusion}

Having investigated the coverage of the Paralympics in the NYT from 1955-2012, we draw two conclusions: [1] NYT media coverage of the Paralympics is minimal and [2] NYT media coverage mostly portrays Paralympic athletes in stereotypical ways, such as supercrips or suffering entities. Both the invisibility of the Paralympics [36] and the stereotypical portrayal of Paralympic athletes [28,79] have been reported for other news sources. The gender/race/ethnicity/sexual orientation angle of disabled athletes is in general an under-investigated and underreported angle within the media and elsewhere, and the same is true for the NYT, although research shows that gender, race/ethnicity and sexual orientation affect the way in which individual athletes are portrayed in the media [114-119]. Simon Darcy, an Associate Professor from Australia, who covered extensively disability sport on various levels, highlighted how, during the 2000 Sydney Olympics ,the Official Olympic Games Ticket Book produced by the Sydney Organizing Committee for the Olympics Games had the following in the section of frequently asked questions, "I am confined to a wheelchair. Will I miss out on the Games?" [33]. Further perpetuation of the demonization of using wheelchairs and the disabling of their users is evident today in articles discussing wheelchair users as "wheelchair-bound" [120,121] in sport.

Given the lack of visibility of the Paralympics in the NYT and the stereotypical portrayal of Paralympic athletes in the NYT, it seems that the vision of the IPC "to create the conditions for athlete empowerment through self-determination" [13] not only is not translated through the NYT, but might be hindered by the reporting of the NYT. Media narratives of the suffering entity and other negative and often medical textual imageries of people with disabilities and the supercrip athlete reinforce social disablement [87]. The supercrip image is attached to the most successful Paralympic athletes who win and gain relatively high profile media exposure; those athletes who win, but do not receive recognition, are not considered supercrips in the context of the Paralympics, as they are often marginalized by the degree or nature of their impairment [30]. In the same way, a winning wheelchair athlete is seen as the epitome of rehabilitative success; bravery in overcoming the catastrophe of a damaged body is a quality many can admire [122]. It appears that in Paralympic track and field athletics, the closer a body is to a cyborg, the more capital it holds [30]. Paralympian wheelchair racers and prosthetic-wearing athletes are the most explicit examples of cyborgification in sport today [30]. There is a hierarchy of 'acceptable' impairment within the community of athletes. Moreover, the more minimally impaired a wheelchair athlete is, the more likely that they will become the embodiment of a supercrip [82]. Societal marginalization of Paralympic athletes is achieved through the media portrayal of Paralympic athletes as vulnerable, afflicted, injured, miserable, distressed and in pain [30]. Consequently, the wish to see disabled people who 'have done it' is particularly intense, while the pitiful disabled trigger antipathy, because they reproduce and reinforce disabled people's inferior positionality and exclusion [30]. This image was based on the public finding inspiration in 'the disabled' overcoming their 'deficits' through sporting participation and being 'here' [33]. The official 
song of the Sydney Paralympics, 'Being Here' presented a non-disabled, ableist and patronizing image of the Paralympic experience and of disability in general [33]. According to Darcy, "The message clearly seeks to evoke sympathy from the public for the inspirational performances of the disabled that had been linked with past Paralympics" [33]. At the same time, a supercrip understanding of therapeutics is developing, where the Paralympian is able to out-compete their Olympic counterpart. In this way, the Paralympics could be a stepping-stone to a higher-level Olympiad event.

The issue of low participation of people with disabilities in sport, despite the increased number of athletes with disabilities competing in the Paralympics, described by Walker-Young as the lack of a trickle-down effect [10], can be given thrust by and may be in part due to the NYT's and other media's use of negative rhetoric and exhibition of supercrip stereotypes utilized to express marginalizing and stigmatizing images of athletes with disabilities and, by extension, people with disabilities. Given that the most visible Paralympians in the NYT are athletes that compete in the Olympics or against "ablebodied" athletes, it is important to question what narrative this might imply in the broader context of people with disabilities participating in Paralympic or recreational level sport. This narrative might place pressure on people participating at different levels of sport to achieve Olympic status, for Paralympians and competitive status against "able-bodied" people and for people with disabilities in mainstream recreational sport. Barriers to sport participation, such as low income, lack of accessibility and unaffordability of technological therapeutic enhancement products, lack of social support and opportunity toward sport and low self-esteem and marginalized segregation from society are not diminished through the way the NYT and other media portray Paralympians and the Paralympics. The portrayal, as evident in the NYT, also, for the most part, does not help to further the discussion around the future of the Paralympics and its relationship with the Olympics. We submit that the coverage of the Paralympics has to increase and change in order to empower people with disabilities to have choice in sport disciplines and to encourage them to partake in sport on all levels.

\section{Acknowledgments}

This work was supported by a Social Sciences and Humanities Research Council of Canada grant obtained by GW. We thank the WolbPack for their help. We also wish to thank the reviewers for their thoughtful comments.

\section{References and Notes}

1. Canadian Parks and Recreation Association (CPRA) Benefits of Parks and Recreation Home Page. http://www.cpra.ca/main.php?action=cms.initBeneParksRec (accessed 23 September 2012).

2. International ParalympicCommittee (IPC) and Rehabilitation International (RI). Disability Right Toolkit; International Paralympic Committee (IPC) and Rehabilitation International (RI), 2008.

3. European Parliament . Situation of disabled people in the enlarged European Union: the European Action Plan 2006-2007. INI/2006/2105. 2006.

4. Lundberg, N.R.; Groff, D.G.; Zabriskie, R.B. Psychological Need Satisfaction through Sports Participation among International Athletes with Cerebral Palsy. Annals of Leisure Research 2010, 13, 102-115. 
5. Campbell, E.; Jones, G. Psychological well-being in wheelchair sport participants and nonparticipants. $A P A Q$ 1994, 11, 404-415.

6. Vliet, P.V.; Biesen, D.V.; Vanlandewijck, Y.C. Athletic identity and self-esteem in Flemish athletes with a disability. European Journal of Adapted Physical Activity 2011, 1, 1.

7. Ferreira, J.P.; Fox, K.R. Self-perceptions and exercise in groups with special needs. In Physical Activity and promotion of Mental Health, Ferreira, J. P., Gaspar, C., Fontes Ribeiro, A. M., Senra, C., Eds.; Portugal: Faculdade de Ciências do Desporto e Educação Física - Universidade de Coimbra, Coimbra, 2004; pp 33-40.

8. Kew, F. Sport: Social problems and issues; Butterworth, Heinemann: Oxford, UK, 1997.

9. Brittain, I. Perception of disability and their impact upon involvement in sports for people with disabilities at all levels. Journal of Sports \& Social Issues 2004, 28, 429-452.

10. Morris, J. Former swimmer hopes to bring athlete's view to job as Paralympic assistant chef; Former Paralympic swimmer named assistant chef. The Canadian Press, Toronto, 2010.

11. Hannon, F. Promoting the Participation of People with Disabilities in Physical Activity and Sport in Ireland. National Disability Authority, Ireland Home Page. http://www.nda.ie/cntmgmtnew.nsf/0/7020D28F7F65773A802570F30057F05E/\$File/Promoting _Participation_Sport.pdf (accessed 23 September 2012).

12. Lakowski, T.; Long, T. Proceedings: Physical Activity and Sport for People with Disabilities. Washington, DC: Georgetown University Center for Child and Human Development Home Page.

http://www.gucchdgeorgetown.net/ucedd/documents/athletic_equity/Physical_Activity_Proceedi ngs.pdf (accessed 23 September 2012).

13. International Paralympic Committee (IPC) Vision, Mission \& Values. International Paralympic Committee (IPC) Home Page. http://www.paralympic.org/IPC/Vision_Mission_Values.html (accessed 23 September 2012).

14. Nord, D.P. A Republican Literature: A Study of Magazine Reading and Readers in Late Eighteenth-Century New York. American Quarterly 1988, 40, 42-64.

15. Weiner, B.I. The Americanization and Periodical Publication, 1750-1810. Cercles 2009, 19, $102-113$.

16. Weinstock Netanel, N. Copyright and a Democratic Civil Society. Yale Law Journal 1996, 106, 292-392.

17. Wallack, L. Mass media and health promotion: Promise, problem and challenge. In Mass communication and public health: Complexities and conflicts, Atkins, C., Wallack, L., Eds.; Sage: Newbury Park, CA, 1990.

18. Burns, A.S. Beard v. Banks: Restricted reading, rehabilitation and prisoners' first amendment rights. Journal of Law and Policy 2007, 15, 1225-1270.

19. Kellner, D. Media culture: Cultural studies, identity and politics between the modern and the postmodern; Psychology Press: London, UK, 1995.

20. Noelle-Neumann, E. Wirkung der Massenmedien auf die Meinungsbildung. Fischer Lexikon Publizistik Massenkommunikation 1994, 5, 518-570.

21. Schantz, O.J.; Gilbert, K. An ideal misconstrued: newspaper coverage of the Atlanta Paralympic Games in France and Germany. Sociology of Sport Journal 2001, 18, 69-94. 
22. Brisenden, S. Independent Living and the Medical Model of Disability. Disability \& Society 1986, 1, 173-178.

23. Learned, W.S. The American Public Library And The Diffusion Of Knowledge; Carnegie Foundation: New York, 1924.

24. Lazarsfeld, P.F.; Merton, R.K. Mass communication, popular taste and organized social action. Media Studies: A Reader, 2nd edn. (Edinburgh: Edinburgh University Press, 1999) 1971, 18-30.

25. Duffy, J.; Yeargeau, M. Editors' Introduction. Disability Studies Quarterly 2011, 31, 3.

26. Barnes, C. Disabling imagery and the media: An exploration of the principles for media representations of disabled people; BCODP London: 1992.

27. Goggin, G.; Newell, C. Crippling paralympics?: Media, disability and olympism. Media International Australia, Incorporating Culture \& Policy 2000, 97, 71.

28. Myers Hardin, M.; Hardin, B. The 'Supercrip' in sport media: Wheelchair athletes discuss hegemony's disabled hero. Sociology of Sport Online 2004, 7, 1.

29. Howe, P.D. From Inside the Newsroom. International Review for the Sociology of Sport 2008, 43, 135-150.

30. Howe, P.D. Cyborg and Supercrip: The Paralympics Technology and the (Dis) empowerment of Disabled Athletes. Sociology 2011, 45, 868-882.

31. MacDonald, M. 6 Media and the Paralympic Games. The Paralympic Games: Empowerment Or Side Show? 2009, 1, 68.

32. Stein, J.U. US media where were you during the 1988 Paralympics? Palaestra, Summer 1989, $45-52$.

33. Darcy, S. The politics of disability and access: the Sydney 2000 Games experience. Disability \& Society 2003, 18, 737-757.

34. Fay, T.; Burton, R.; Grevemberg, D. A marketing analysis of the 2000 Paralympic Games: are the components in place to build an emerging global brand? CSSS Staff Presentations. Paper 2 Home Page. http://iris.lib.neu.edu/cgi/viewcontent.cgi?article $=1001 \&$ context=sport_staff_pres (accessed 23 September 2012).

35. Wickman, K. Bending mainstream definitions of sport, gender and ability: Representations of wheelchair racers. (doctoral dissertation), Department of Education, Umeå University, Sweden Home Page. Available online: http://umu.divaportal.org/smash/get/diva2:141458/FULLTEXT01 (accessed 23 September 2012).

36. Golden, A. An analysis of the dissimilar coverage of the 2002 Olympics and Paralympics: Frenzied pack journalism versus the empty press room. Disability Studies Quarterly 2003, 23, $3-4$.

37. Ellis, K. Beyond the Aww Factor: Human interest Profiles of Paralympians and the media navigation of physical difference and social stigma. Asia Pacific Media Educator 2008, 19, 23.

38. The New York Times Company About the Company: Pulitzer Prizes. New York Times Company Home Page. http://www.nytco.com/company/awards/pulitzer_prizes.html. (accessed 23 September 2012).

39. Althaus, S.L.; Tewksbury, D. Agenda setting and the "new" news patterns of issue importance among readers of the paper and online versions of the New York Times. Communication Research 2002, 29, 180-207. 
40. Iyengar, S.; Kinder, D. R. News that matters: Television and American opinion; University of Chicago Press: 2010.

41. The A. P., "Without a Physical Director," New York Times (1923-Current file), 12 April 1894, p3.

42. Associated Press British Olympic Plans Are Delayed for Lack of Funds. New York Times, 1920, p 14.

43. Rusk, H. Sports Competition a Boon To Health of Handicapped. New York Times, 1952, p 47.

44. 11 Fly to Paralympics. New York Times (1923-Current file), Jul 27, 1955, p 26.

45. Smothers, R. Welcoming the Disabled, Atlanta Lets the Games Begin, Again. New York Times, Aug 15, 1996, p -25.

46. Ridgley, G. The media and the Paralympics Home Page. http://www.bl.uk/sportandsociety/exploresocsci/sportsoc/media/articles/paramedia.html (accessed 23 September 2012).

47. Peers, D. (Dis) empowering Paralympic histories: absent athletes and disabling discourses. Disability \& Society 2009, 24, 653-665.

48. Wolbring, G. Oscar Pistorius and the Future Nature of Olympic, Paralympic and Other Sports. SCRIPTed - A Journal of Law, Technology \& Society 2008, 5, 139-160.

49 The, A.P. Pistorius Sprints to Gold in First of His Three Races. New York Times, Sep 10, 2008, p - D6.

50. Vecsey, G. Strides, Often Painful,, but Always, Always Forward. New York Times, Apr 26, 2010, $\mathrm{p}-\mathrm{D} 5$.

51. Schwarz, A. A Severely Injured Soldier Re-emerges as a Sprinter. New York Times, Aug 14, 2009, $p-B 9$.

52. The, A.P. Pistorius Upset in 200 Meters. New York Times, Sep 3, 2012, p -D4.

53. Sarah, M.N. Paralympians' Equipment Raises Debate on Fairness. New York Times, Sep 9, 2012, $\mathrm{p}-\mathrm{SP} 8$.

54. Longman, J. Embracing the Equality of Opportunity. New York Times, Aug 18, 2008, p -D1.

55. The, A.P. China Back On Global Sports Stage. New York Times, Sep 7, 2008, p -SP12.

56. The, A.P. After Olympic Disappointment, Gold at Paralympics. New York Times, Sep 8, 2008, p - D6.

57. The, A.P. South African Swimmer Wins Her Fourth Gold Medal. New York Times, Sep 13, 2008, $\mathrm{p}-\mathrm{D} 6$.

58. Longman, J. Debate on Amputee Sprinter: Is He Disabled or Too-Abled? New York Times, May 15, 2007, $\mathrm{p}-\mathrm{A} 1$.

59. Longman, J. It's all in the timing. New York Times, 16 June 1995, B8.

60. Vecsey, G. The Amateur Ideal: Voters Know a Star When They See One. New York Times, Apr 15, 2007, p H3.

61. Dajani, K. Other Research-What's in a Name? Terms Used to Refer to People With Disabilities. Disability Studies Quarterly 2001, 21, 3.

62. The A.P.,"Paralympic Group Orders Suspensions," New York Times, 30 January 2001, D7

63. Special to The New York Times Money Troubles Eased in Wheelchair Games. New York Times (1923-Current file), Mar 13, 1984, p 1. 
64. By The New York Times Safety of the Summer Games Still Worrying Organizers. New York Times (1923-Current file), Jun 29, 1996, p 29.

65 Schwarz, A. Court lets ruling stand in U.S.O.C. case; [Sports desk]. New York Times, 7 October 2008, p. B20.

66. Vecsey, G. Still Living on the Line. New York Times (1923-Current file), Aug 19, 1988, p.D19.

67. Schwirtz, M. Disabled Athletes Defy an Unaccommodating City. New York Times, May 21, 2010, p A10.

68. Lyall, S. At Paralympics, First Thing Judged Is Disability. New York Times, Sep 1, 2012, p -A1.

69. Schwarz, A. A Disabled Swimmer's Dream, a Mother's Fight. New York Times, Jun 18, 2008, p $-\mathrm{A} 1$.

70. Museler, C. Nick Scandone, 42, Winner Of Paralympics Sailing Gold. New York Times, Jan 5, 2009, $\mathrm{p}-\mathrm{B} 7$.

71. Frosch, D. Warriors Forever. New York Times, May 22, 2011, p-SP4.

72. Schwarz, A. The Art and Science of Wheelchair Basketball. New York Times, 9 September 2008, SP5.

73. International Paralympic Committee IPC classification code and international standard . International Paralympic Committee Home Page. http://www.paralympic.org/sites/default/files/document/120201084329386_2008_2_Classificatio n_Code6.pdf (accessed 23 September 2012).

74. Barnes, C. Discrimination: disabled people and the media. Contact 1991, 70, 15-19.

75. Harnett, A. Escaping the ôevil avengerö and the ôsupercripö: images of disability in popular television. Irish Communications Review 2000, 8, 21-29.

76. Kama, A. Supercrips versus the pitiful handicapped: Reception of disabling images by disabled audience members. Communications 2004, 29, 447-466.

77. Meeuf, R. John Wayne as" Supercrip": Disabled Bodies and the Construction of" Hard" Masculinity in The Wings of Eagles. Cinema Journal 2009, 48, 88-113.

78. Booher, A.K. Docile bodies, supercrips and the plays of prosthetics. International Journal of Feminist Approaches to Bioethics 2010, 3, 63-89.

79. Hardin, M.; Hardin, B. How elite wheelchair athletes relate to sport media. The Paralympic Games: Empowerment or sideshow 2008, 25-33.

80. The Associated Press, "Wheel Chair Unit a Victor in Sports: Polio Victims, All with PanAmerican Airways, Tell of English Triumphs," New York Times, 3 August 1955, p.16.

81. Vecsey, G. Other games headed to town. New York Times, 26 February 2002, D1.

82. Berger, R.J. Disability and the Dedicated Wheelchair Athlete. Journal of Contemporary Ethnography 2008, 37, 647-678.

83. Cherney, J.L.; Lindemann, K. Sporting Images of Disability. Examining identity in sports media 2009, 195, 1 .

84. Olenik, L.M.; Matthews, J.M.; Steadward, R.D. Women, Disability and Sport: Unheard Voices. Canadian Woman Studies 1995, 15, 4.

85. Schell, L.A.; Duncan, M.C. A content analysis of CBS's coverage of the 1996 Paralympic Games. Adapted Physical Activity Quarterly 1999, 16, 27-47. 
86. Scott Hogsett as told do Dana Adam Shapiro Not One for the Sidelines. New York Times (1923Current file), Sep 19, 2004, p 140.

87. Ellis, K. Beyond the Aww Factor: Human interest Profiles of Paralympians and the media navigation of physical difference and social stigma. Asia Pacific Media Educator 2009, 1, 2336.

88. By Tony Kornheiser Special to The New York Times Desire Spurs Top Athletes On Wheels. New York Times (1923-Current file), Jun 12, 1976, p 39.

89. Wilson, E. Model and Front-Runner. New York Times, Jul 14, 2011, p -E1.

90. Dewan, S. A long-ago refuge still tends to the needs of polio survivors. 2005.

91. By Howard, A. Rusk. Paralyzed Athletes, With Big Victories Behind Them, Open Olympics This Week. New York Times (1923-Current file), Sep 18, 1960, p 134.

92. Purdue, D.E.J.; Howe, P.D. See the sport, not the disability: exploring the Paralympic paradox. Qualitative Research in Sport, Exercise and Health 2012, 4, 189-205.

93. Trumbull, R. 369 to compete in Paralympics: wheelchair games due to open at Tokyo today. New York Times, 8 November 1964, S2.

94. Special to The New York Times Elite Athlete Chases More Than a Medal. New York Times, Jul 17, 1991, p-B11.

95. Litsky, F. A Blind Rider Races Into the Nationals. New York Times, Jul 12, 1997, p 31.

96. On your own; One-Legged Runner Tries to Inspire Others. New York Times, Jul 16, 1990, p C10.

97. Museler, C. Unforeseen Change of Course. New York Times, Feb 9, 2008, p 0-D.

98. Wolbring, G. Paralympians outperforming Olympians: An increasing challenge for Olymp-ism and the Paralympic and Olympic movement. Sport, Ethics and Philosophy 2012.

99. Wolbring, G.; Legg, D.; Stahnisch, F. W. Meaning of Inclusion throughout the History of the Paralympic Games and Movement. The International Journal of Sport \& Society 2010, 1, 81-93.

100. Howard, H. Park city center offers a new rush for athletes with disabilities. New York Times, 18 December 2005, D2.

101. Schwarz, A. The Art and Science of Wheelchair Basketball. New York Times, Sep 9, 2008, p SP2.

102. El-Bashir, T. Amputee takes sheer speed and will to Atlanta. New York Times, 16 August 1996, B13.

103. Dicker, R. New equipment stirs division within wheelchair ranks. New York Times, 5 November, 2000, SP9.

104. Vecsey, G. Sports of The Times; Still Living on the Line. New York Times, Aug 19, 1988, p -D.

105. Martin, D. After the olympics, games of another kind begin. New York Times, 23 September 1988, p.A1.

106. Helou, P. Article 7 - No title. New York Times, 26 May 1991, L14.

107. Ryan, B. It's Back to Barcelona: Let the Games Begin Once Again! New York Times, Aug 30, 1992, $\mathrm{p}-\mathrm{CN} 1$.

108. Hirschberg, L. Hot wheels. New York Times, 10 July 2005, 42-47.

109. Holden, S. These Gladiators on Wheels Are Not Playing for a Hug. New York Times, Jul 8, 2005, p E8 
110. Holden, S. These gladiators on wheels are not playing for a hug. 2005.

111. Wheelchair games; Racing Off To New Athletic Titles. New York Times, Jul 23, 1993, p -B18.

112. Longman, J. New York City Marathon; Proceeding With Caution. New York Times, Nov 7, 1995, $\mathrm{p}-\mathrm{B} 9$.

113. Longman, J. New York City Marathon; Proceeding With Caution. New York Times, Nov 7, 1995, $\mathrm{p}-\mathrm{B} 9$.

114. Lindfelt, M. Elite sports in tension: making identification the core moral norm for professional sports in the future. Sport in Society: Cultures, Commerce, Media, Politics 2010, 13, 186-198.

115. Billings, A.C. Talking Around Race: Stereotypes, Media and the Twenty-First Century Collegiate Athlete. Wake Forest JL \& Pol'y 2012, 2, 199-533.

116. Grainger, A.; Newman, J.I.; Andrews, D.L. Chapter 27-Sport, the Media and the Construction of Race. Routledge Online Studies on the Olympic and Paralympic Games 2012, 1, 482-504.

117. Knight, J.L.; Giuliano, T.A. He's a Laker; she's a looker: The consequences of genderstereotypical portrayals of male and female athletes by the print media. Sex Roles 2001, 45, $217-$ 229.

118. Polney, M.P. Gendered representations of college athletes: a content analysis of newspaper coverage of March Madness. 2012.

119. Riebock, A. Sexualized Representation of Female Athletes in the Media: How Does it Affect Collegiate Female Athlete Body Perceptions? 2012.

120. Hachman, M. Prosthetic Limbs Give Runner Unfair Advantage. Extremetech Magazine Home Page. http://www.extremetech.com/computing/80926-prosthetic-limbs-give-runner-unfairadvantage (accessed 23 September 2012).

121. Michaelis, V. Running down a dream: Leg amputee makes U.S. track team. USA Today Home Page. http://www.usatoday.com/sports/olympics/summer/track/2010-04-25-amputeerunner_N.htm (accessed 23 September 2012).

122. Seymour, W. Remaking the Body: Rehabilitation and Change; 1998.

(C) 2013 by the authors; licensee MDPI, Basel, Switzerland. This article is an open access article distributed under the terms and conditions of the Creative Commons Attribution license (http://creativecommons.org/licenses/by/3.0/). 